Journal of Biomedical and Pharmaceutical Research

Available Online at www.jbpr.in

CODEN: - JBPRAU (Source: - American Chemical Society)

NLM (National Library of Medicine): ID: (101671502)

Index Copernicus Value 2018: 88.52

Original Research Article

Volume 10, Issue 4: September-October: 2021, 15-19

ISSN (Online): 2279-0594

ISSN (Print): 2589-8752

\title{
Molecular Detection of HSV type 2 Infection among Infertile Males in Khartoum State, Sudan
}

\section{Mai Elhadi ${ }^{1}$, Abdel Rahim M El Hussein ${ }^{2}$, Mohamed O Mustafa ${ }^{1}$, Isam M Elkhidir $^{3}$ and Khalid A Enan ${ }^{* 2}$}

${ }^{1}$ Department of Medical Microbiology, Faculty of Medical Laboratory Science, El Neelain University, Khartoum, Sudan

${ }^{2}$ Department of Virology, Central Laboratory, Ministry of Higher Education and Scientific Research, Khartoum, Sudan

${ }^{3}$ Department of Microbiology and Parasitology, Faculty of Medicine, University of Khartoum, Sudan

Article Info: Received 22 July 2021; Accepted 29 September 2021

DOI: https://doi.org/10.32553/jbpr.v10i5.878

Corresponding author: Khalid A Enan

Conflict of interest statement: No conflict of interest

\begin{abstract}
Background: Herpes simplex virus (HSV) infections of humans were first documented in ancient Greece. HSVs belong to family Herpesviridae, and are characterized by being enveloped, doublestranded DNA viruses with relatively large complex genomes. Herpes simplex virus type 2 (HSV-2) DNA seems to play a significant role in male infertility, it is significantly related to low sperm count as well as poor motility.

Aim: This study aimed to determine the incidence of HSV-2 DNA among infertile males in Khartoum State, Sudan by using molecular methods.

Methods: The study was carried out in Khartoum State, Sudan, during May-August 2018. A total of 50 semen samples from infertile males were included. HSV-2 was detected using real-time polymerase chain reaction (RT-PCR).
\end{abstract}

Result: Among 50 semen samples from infertile males, 6(12\%) samples were found positive for HSV2 DNA.

Conclusion: Our findings showed no association between HSV-2 DNA and low sperm count in infertile Sudanese men. Our study also revealed the need for further investigations in different parts of the country to highlight the extent of the viral related men infertility problem in Sudan.

Keywords: HSV-2, RT-PCR, infertility, men, Sudan

\section{Introduction}

Herpes simplex virus (HSV) infections of humans were first documented in ancient

Greece. Greek scholars, particularly Hippocrates, used the word "herpes," meaning 
to creep or crawl, to describe spreading lesions. The classification now in use came into being in the late eighteenth century, and although the vesicular nature of lesions associated with herpetic infections was previously well characterized, it was not until 1893 that Vidal specifically recognized person-to-person transmission of HSV infections ${ }^{(1)}$.

Herpesviruses belong to family Herpesviridae, that are enveloped, double-stranded DNA viruses with relatively large complex genomes. They replicate in the nucleus of a wide range of vertebrate hosts cells ${ }^{(2)}$.

Human herpesviruses infections are endemic and sexual contact is a significant mode of transmission for several including both HSV-1, HSV-2, also human cytomegalovirus (HHV-5) and likely Karposi's sarcoma herpesvirus (HHV8). The increasing prevalence of genital herpes and corresponding rise of neonatal infection and the suggestion of Epstein-Barr virus (HHV-4) and Karposi's sarcoma herpesvirus as cofactors in human cancers created an urgent need for a better understanding of this complex, and highly successful virus family ${ }^{(3)}$.

HSV-2 continues to be a common infection, affecting approximately $22 \%$ of adults ages 12 and older, representing 45 million adults in the United States alone (4). HSV-2 is more commonly the prime suspect when patients present with genital lesions. Despite this, most outbreaks of the infection will present with nonspecific symptoms such as genital itching, irritation, and excoriations ${ }^{(4)}$. HSV-2 is mainly transmitted through sexual coitus, contributing to its predominant rise starting at puberty ${ }^{(5)}$.

HSV-2 DNA seems to play a significant role in male infertility, it is significantly related to low sperm count as well as poor motility ${ }^{(6)}$ and has been detected by polymerase chain reaction (PCR) technique in the sperm of men with genital HSV-2 infection ${ }^{(7,8)}$.

\section{Material and Methodology}

\section{Study design}

This is a Cross sectional study carried out in Khartoum State's hospitals.

\section{Clinical samples}

A total of 50 semen samples were collected from patient groups at Khartoum State, between May and August 2018. Patients included in this study were infertile men and were given a written informed consent to participate.

Semen samples $(3 \mathrm{ml})$ in cryovials tubes, were collected from males after ejaculation and stored immediately at $-20 \mathrm{C}^{\circ}$ for DNA extraction for RT-PCR. Morphology was done by strict Kruger method and total number count of sperm was done using routine counting procedure (improved Neubauer haemocytometer).

\section{DNA extraction kits}

Commercial kit Q1Aamp viral DNA mini kits (Qiagen, Germany) were used to extract DNA of HSV-2 according to procedure described by manufacture. The viral DNA was finally eluted in $60 \mu \mathrm{l}$ of elution buffer and stored at $-20^{\circ} \mathrm{C}$

\section{RT-PCR}

Bio-Rad (USA) commercial kits were used according to manufactures instructions.

\section{Results}

Semen samples had a homogeneous, greyopalescent appearance and were less opaque due to low sperm concentration. Sperms had low motility, less than (40\%). Morphology done by strict Kruger method, showed normal sperm morphology (1-3\%) and abnormal (defect sperms) morphology (97-99\%). Total number count of sperm done by routine counting procedure (improved Neubauer haemocytometer), revealed that all samples have low sperm count. In samples numbered from 1 to 16 the counts were less than $10 \times 10^{6}$ sperm per millimeter, indicating very low count (cryptozoospermia), and for samples numbered 17 to 50 the count were from $10-20 \times 10^{6}$ sperm per millimeter. 
6 of the 50 semen samples from infertile males were found positive for HSV-2 DNA as shown in table 1. More positive HSV-2 DNA was detected in 4 low count (less than $10 \times 10^{6}$ ) samples while only 2 samples were positive in the higher count $\left(10-20 \times 10^{6}\right)$ samples,

Table 1: HSV2 DNA in infertile males in Khartoum State detected by PCR (2018).

\begin{tabular}{|l|l|l|l|}
\hline Sperm count & Positive (\%) & Negative (\%) & Total (\%) \\
\hline Less than $10 \times 10^{6}$ & $4(8)$ & $12(24)$ & $16(32)$ \\
\hline From $10-20 \times 10^{6}$ & $2(4)$ & $32(64)$ & $34(68)$ \\
\hline Total & $6(12)$ & $44(88)$ & $50(100)$ \\
\hline
\end{tabular}

\section{Discussion}

About $50 \%$ of infertility cases are due to male factors. In the majority of male infertility cases, the cause of infertility remains unknown ${ }^{(9)}$ The major causes of male infertility include varicocele, hormonal disturbances, immunological conditions, genital duct obstruction, cryptorchidism, medications, gonadotoxins, infectious diseases, sexual dysfunction, and ejaculatory failure (10). Infections may deteriorate fertility by damaging spermatogenesis, impairment of sperm function, and occlusion of the seminal tract (11). A mounting body of evidence now indicate that viral infections play a role in the pathogenesis of male infertility. Viral infections may reduce male fertility, either directly, or indirectly by invading the male genital tract cells or by causing local inflammatory or immunological responses that might deteriorate reproductive functions by proinflammatory cytokines and reactive oxygen species ${ }^{(12,13)}$.

The role of some viral infections in male infertility has been investigated, and many previous studies revealed that HSV infections were associated with abnormal sperm parameters ${ }^{(14-16)}$.HSV-2 is mainly transmitted through sexual intercourse, contribuing to its predominance starting at puberty and seems to play important role in male infertility.
Kotronias et al. ${ }^{(17)}$ detected HSV-1 and HSV-2 infections in the semen of $21 \%$ and $20 \%$ of infertile men, respectively. Moreover, HSV infection was related with reduced sperm count and reduced motility. In another study by Monavari et al, HSV-1 and HSV-2

DNA was detected in 16 (22.9\%) and 10 (14.3\%) of 70 semen samples, respectively. All HSVpositive samples had abnormal semen parameters (18). In yet another study by Kapranos et al. ${ }^{(19)}$, HSV DNA was detected in $49.5 \%$ of semen samples and HSV infection was significantly related to low sperm count as well as poor motility. In the present study, lower incidence rate (12\%) was detected in Sudanese patients. This relatively lower positivity might be rooted in the conservative nature of the Sudanese society which prohibits extramarital relationships. Similar to other studies $^{(17,19)}$, however, our study showed that HSV-2 may be implicated in lower sperm counts in the infected patients as most of the positive patients $(n=4,67 \%)$ were cryptozoospermia patients..

Due to logistical reasons we were not able to test our patients for HSV 1 and other herpesviruses, that would have given us a more complete depiction of the implications of these viruses infections in men infertility cases in 
Sudan. Thus more detailed investigations are required in this domain of study.

\section{Conclusion}

Detection of HSV-2 DNA in cases of men infertility by using RT-PCR is fast, accurate, sensitive, simple and more practical method for diagnosis.

Our findings show no association between HSV2 DNA and low sperm count. Our study also reveals the need for further investigations in different parts of the country to highlight the extent of the viral related men infertility problem in Sudan.

\section{References}

1. Wildy P, Herpes: history and classification. In: Kaplan AS, ed. The herpes viruses. New York: Academic Press, 1973:1-25.

2. Sexually Transmitted Diseases, third edition (1999), ed. Holmes et al., pub. McGraw Hill.

3. Peter E. Pertel, Patricia G. Spear, chapt. 20, "Biology of Herpesviruses" Peter Piot, Stanley Lemon, King Holmes, Per-Anders Mardh, Judith Wasserheit, P. Sparling, Walter Stamm. Sexually Transmitted Diseases 3rd edition. Pub. Date: 16-Nov1998.

4. Fleming DT, Leone $P$, Esposito $D$, Heitman CK, Justus S, Chin S, Fife KH. Herpes virus type 2 infection and genital symptoms in primary care patients. Sex Transm Dis. 2006 33(7):416-21.

5. Sauerbrei A. Herpes Genitalis: Diagnosis, Treatment and Prevention. Geburtshilfe Frauenheilkd. 2016 Dec;76(12):1310-1317. [PMC free article] [PubMed]

6. Kapranos N, Petrakou E, Anastasiadou C, Kotronias D. Detection of herpes simplex virus, cytomegalovirus, and Epstein-Barr virus in the semen of men attending an infertility clinic. Fertil Steril 2003;79 Suppl 3:1566-70

7. Aynaud O, Bijaoui G, lonesco M, Corgette O, Poveda JD, Zummer K. Genital herpes simplex virus infection among men screened for genital papillomavirus. Ann Dermatol Venereol 1994;121:376-81.

8. Wald A, Matson P, Ryncarz A, Corey L. Detection of herpes simplex virus DNA in semen of men with genital HSV-2 infection. Sex Transm Dis 1999;26:1-3.

9. Leru ez-Ville M, Galimand J, Ghosn J, Briat A, De-laugerre $C$, Chaix ML. Male genital tract infection: the point of view of the virologist. Gynecol Obstet Fertil 2005; 33:684-90.

10. Greenberg SH, Lipshultz LI, Wein AJ. Experience with 425 sub-fertile male patients. J Urol 1978; 119: 507-10.

11. Bar-Chama N, Fisch H. Infection and pyospermia in male infertility. World J Urol 1993; 11: 76-81. Purvis K, Christiansen E. The impact of infection on sperm quality. Human Reprod 1996; 11: 31-41.

12. Comhaire FH, Mahmoud AM, Depuydt CE, Zalata AA, Christophe AB. Mechanisms and effects of male genital tract infection on sperm quality and fertilizing potential: the andrologist's viewpoint. Hum Reprod Update 1999; 5: 393-8.

13. Agarwal A, Makker K, Sharma R. Clinical relevance of oxidative stress in male factor infertility: an update. Am J Reprod Immunol 2008; 59: 2-11.]

14. Lai YM, Lee JF, Huang HY, Soong YK, Yang FP, Pao CC. The effect of human papi II omavirus infection on sperm cell motility. Fertil Steril 1997; 67: 1152-5.

15. Erles K, Rohde V, Thaele M, Roth S, Edler $L$, Schle-hofer JR. DNA of adenoassociated virus (AAV) in testicular tissue and in abnormal semen samples. Hum Reprod 2001; 16: 2333-7.

16. Dejucq N, Jégou B. Viruses in the mammalian male genital tract and their effects on the reproductive system. Microbiol Mol Biol Rev 2001; 65: 208-31.

17. Kotronias D, Kapranos N. Detection of herpes simplex virus DNA in human 
spermatozoa by in situ hybridization technique. In Vivo 1998; 12: 391-4.

18. Seyed HM, Mostafa SV, Mohammadali K, Mahmoud SS, Hossein K, Hamidreza M, Mehdi F. Asymptomatic seminal infection of herpes simplex virus: impact on male infertility The J of Biomed Res 2013, 27(1): 56-61

19. Kapranos N, Petrakou E, Anastasiadou C, Kotronias D. Detection of herpes simplex virus, cytomegalovirus, and Epstein-Barr virus in the semen of men attending an infertility clinic. Fertil Steril 2003; 79: 1566-70. 